\title{
Differences between literature and arts in the context of language
}

Ahmet ihsan Kaya *,

Suggested Citation:

Abstract 
1. Introduction

2. On Literature 
3. Differences of literature from other arts 
4. Result

\section{References}

